\title{
Genetic and Environmental Components of Interindividual Variation In Circulating Levels of IGF-I, IGF-II, IGFBP-1, and IGFBP-3
}

\author{
M. Harrela, ${ }^{\star}$ H. Koistinen, ${ }^{\star}$ J. Kaprio, ${ }^{\ddagger}$ M. Lehtovirta, ${ }^{\S}$ J. Tuomilehto, J. Eriksson, ${ }^{\|}$L. Toivanen, ${ }^{\|}$M. Koskenvuo, ${ }^{\ddagger}$ P. Leinonen, ${ }^{\star}$ \\ R. Koistinen, ${ }^{*}$ and M. Seppälä* \\ *Department of Obstetrics and Gynecology; ${ }^{\circledR}$ Department of Medicine, Division of Internal Medicine, Helsinki University Central \\ Hospital; ${ }^{*}$ Department of Public Health, University of Helsinki and Turku; and ${ }^{\|}$Diabetes Research Centre, Department of Epidemiology \\ and Health Promotion, National Public Health Institute, Helsinki, Finland
}

\begin{abstract}
We assessed the magnitude of the genetic component in the variation of circulating levels of insulin-like growth factors I and II (IGF-I and IGF-II), and their binding proteins IGFBP-1 and IGFBP-3 by measuring their serum concentrations in $\mathbf{3 2}$ monozygotic and $\mathbf{4 7}$ dizygotic adult twin pairs of the same sex. The intrapair correlation for the IGF-I levels was $r=0.41(P<0.009)$ for monozygotic twins and $r=0.12$ $(P<0.22)$ for dizygotic twins. For the IGF-II concentration the intrapair correlations were $r=0.66(P<0.0001)$ for the monozygotic and $r=0.34(P<0.01)$ for the dizygotic twins. No significant intrapair correlation was found for IGFBP-1 levels in either group. The correlations for IGFBP-3 concentration were $r=0.65(P<0.0001)$ and $r=0.23(P<0.06)$ for monozygotic and dizygotic twins, respectively. Women had higher IGF-II levels than men (635 \pm 175 vs. $522 \pm 144$ $\mu \mathrm{g} /$ liter; $P<0.0001)$ and IGFBP-3 levels were also higher in women compared with men $(5441 \pm 1018 \mathrm{vs} .4496 \pm 1084 \mu \mathrm{g} /$ liter; $P<0.001)$. The proportion of variance attributable to genetic effects was $38 \%$ for the IGF-I concentration, $66 \%$ for the IGF-II concentration, and $60 \%$ for the IGFBP-3 concentration. No significant heritability was found for the IGFBP-1 concentrations. Our results show that, in adults, there is a substantial genetic contribution responsible for interindividual variation of the circulating levels of IGF-I, IGF-II, and IGFBP-3, but not for the IGFBP-1 levels. (J. Clin. Invest. 1996. 98:2612-2615.) Key words: twins - monozygotic • dizygotic • genetic regulation • insulin-like growth factor
\end{abstract}

\section{Introduction}

The IGF system plays an important role in cell growth, differentiation, and mediation of the actions of growth hormone (1). It includes insulin-like growth factors I and II, their receptors, and six binding proteins $(2,3)$. Both IGF-I and IGF binding protein-3 (IGFBP-3) ${ }^{1}$ are growth hormone dependent (4),

Address correspondence to Dr. Pekka Leinonen, Department of Obstetrics and Gynecology, University of Helsinki, FIN-00290 Helsinki, Finland. Phone: 358-9-4712811; FAX: 358-9-4712812.

Received for publication 29 April 1996 and accepted in revised form 24 September 1996.

1. Abbreviation used in this paper: IGFBP, insulin-like growth factor binding protein.

J. Clin. Invest.

(C) The American Society for Clinical Investigation, Inc. 0021-9738/96/12/2612/04 \$2.00

Volume 98, Number 11, December 1996, 2612-2615 whereas IGF-II is not (1). IGFBP-3 is a glycoprotein that forms a $140-\mathrm{kD}$ complex with the IGFs and an acid-labile component. IGFBP-3 is the major IGF-binding protein in serum and it serves as a reservoir for the IGFs in circulation. IGFBP-1 is a nonglycosylated $30-\mathrm{kD}$ protein involved in metabolic adaptation to nutritional stimuli and local regulation of the IGF action. The IGFBP-1 levels are down-regulated by insulin (5), and up-regulated by thyroxine $(6,7)$.

Both IGF-I and IGF-II are products of single genes, located on the long arm of chromosome 12, and on the short arm of chromosome 11 , respectively $(8,9)$. The IGFBP-1 gene has been localized to chromosome 7 , where it is contiguous with the gene encoding IGFBP-3 $(10,11)$.

Twin studies are used to estimate the overall contribution of genetic effects in the variation of a given marker. Kao and co-workers found that in children the variation in IGF-I levels is almost completely of genetic origin (12). The present study was undertaken to assess the magnitude of the genetic component in the variation of circulating levels of IGF-I, IGF-II, IGFBP-1, and IGFBP-3 in adult twins.

\section{Methods}

79 twin pairs with a mean age of 65 years (range, 44-77) participating in an ongoing study of glucose metabolism were included in the present study. The pairs were selected from the Finnish Twin Cohort independently of their health status (13). They all were resident in the Helsinki metropolitan area. Zygosity was diagnosed by a questionnaire method according to similarity at school age and validated by blood group testing (14). Serum samples were obtained from the subjects after overnight (more than eight hours) fasting and stored at $-20^{\circ} \mathrm{C}$.

IGF-I was determined from the serum samples using RIA Kits from INCSTAR Corp. (Stillwater, MN). The assay uses acid treatment and ODS-silica gel extraction to dissociate IGF-I from its binding proteins. It had a sensitivity of $2.0 \mathrm{nmol} /$ liter and the intraassay coefficient of variation (SD/mean) was $10 \%$ at the level of $13 \mathrm{nmol} /$ liter.

Monoclonal antibody against recombinant hIGF-II (Austral Biologicals, San Ramon, CA) was generated essentially as described before for another protein (15). IGF-II was measured by a competitive immunofluorometric assay using immobilized monoclonal anti-IGF-II antibody and Europium-labeled recombinant human IGF-II. IGF-II was labeled with the Delfia Eu-labeling reagent (Eu-chelate of isothiocyanatobenzyl-diethylene-triaminetetraacetic acid; Wallac, Tur$\mathrm{ku}$, Finland) (15). For solid-phase coating rabbit anti-mouse immunoglobulins (Dakopatts, Glostrup, Denmark), $2 \mu \mathrm{g} / 200 \mu \mathrm{l}$ Tris buffer (50 mmol/liter Tris-HCl, $\mathrm{pH} 7.7$, containing 9 grams/liter $\mathrm{NaCl}$ and 0.5 grams/liter $\mathrm{NaN}_{3}$ ), were adsorbed onto polystyrene microtiter wells (Eflab, Helsinki, Finland) by an overnight incubation at room temperature. After washing with washing solution (Tris buffer containing 0.5 grams/liter Tween 20) the strips were saturated with $1 \%$ bovine serum albumin for $2 \mathrm{~h}$. Monoclonal mouse anti-human IGF- 
II, clone F69-1F6, $40 \mathrm{ng} / 200 \mu \mathrm{l}$ assay buffer (Tris buffer containing 5 grams/liter bovine serum albumin, 0.5 grams/liter bovine gammaglobulin, 2 grams/liter diethylenetriaminepentacetic acid, and 0.1 grams/ liter Tween 20) were added into the wells and incubated at room temperature. After $1 \mathrm{~h}$ the wells were washed twice with washing solution. The standards were recombinant human IGF-II diluted in normal horse serum (Vector Laboratories, inc., Burlingame, CA) and extracted like the serum samples. The IGFs were separated from the IGFBPs by extraction in formic acid: $50 \mu \mathrm{l}$ serum and $25 \mu \mathrm{l} 8 \mathrm{~mol} / \mathrm{liter}$ formic acid containing $0.05 \%$ Tween 20 were mixed, $175 \mu \mathrm{l}$ ice cold acetone was added, mixed and centrifuged at 5,000 $\mathrm{g} 4^{\circ} \mathrm{C}$ for $15 \mathrm{~min}$. The supernatant $(200 \mu \mathrm{l})$ was transferred to another tube, evaporated under nitrogen for $0.5 \mathrm{~h}$, then dissolved in $200 \mu \mathrm{l}$ distilled water and lyophilized. The lyophilized sample was suspended in $120 \mu \mathrm{l}$ assay buffer.

In the assay, $25 \mu \mathrm{l}$ sample and $150 \mu \mathrm{l}$ assay buffer were added into the antibody coated microtiter wells and, after overnight incubation at $4^{\circ} \mathrm{C}$, Europium-labeled IGF-II $(2 \mathrm{ng} / 50 \mu \mathrm{l})$ was added to the wells and incubated for another $40 \mathrm{~min}$ at room temperature. After washing four times $200 \mu \mathrm{l}$ enhancement solution $(0.1 \mathrm{~mol} / \mathrm{liter}$ acetate phthalate buffer, pH 3.2, containing $0.1 \mathrm{ml} /$ liter Triton X-100, 15 $\mu \mathrm{mol} /$ liter 2-naphthoyl trifluoroacetone, and $50 \mu \mathrm{mol} /$ liter tri-n-octylphosphine oxide; LKB Wallac). The wells were shaken gently for 2 min and the fluorescence was measured by Delfia research fluorometer (model 1234; LKB Wallac). Sensitivity of the IGF-II assay was 120 $\mu \mathrm{g} /$ liter, intraassay coefficients of variation were $7.2 \%$ at $806 \mu \mathrm{g} / \mathrm{liter}$ and $8.6 \%$ at $406 \mu \mathrm{g} / \mathrm{liter}$, and interassay coefficients of variation were $4.9 \%$ at $779 \mu \mathrm{g} / \mathrm{liter}$ and $13 \%$ at $379 \mu \mathrm{g} /$ liter. For analytical recovery IGF-II was added to serum and four separate extractions were assayed in duplicate. Analytical recovery was $75-125 \%$ (Table I). Cross-reactivities were tested with $1 \mathrm{mg} / \mathrm{ml}$ of IGF-I (Austral Biologicals), IGFBP-1 (16), IGFBP-3 (Celtrix Pharmaceuticals) and IGFBP-2, -4, -5, -6 (Austral Biologicals). IGFBPs 1 to 6 and IGF-I did not cross-react in the IGF-II assay when added directly to the immunoassay, nor did they affect the IGF-II levels when added to serum before extraction. The IGF-II standard curve and dilution curve of extracted serum were parallel. Normal serum levels of IGF-II were $653 \pm 126 \mu \mathrm{g} /$ liter (mean $\pm \mathrm{SD}$, range 353-909 $\mu \mathrm{g} / \mathrm{liter}, n=34$ ).

The fasting serum IGFBP-1 concentration was determined by a two-site immunofluorometric assay as described earlier (17) using two monoclonal antibodies, F34-15C9 and F36-9G3. The intra-assay variation was $3-11 \%$, the interassay variation was $4-10 \%$ and the sensitivity of the assay was $0.1 \mu \mathrm{g} / \mathrm{liter}$.

IGFBP-3 was determined from serum samples using monoclonal antibodies $(\mathrm{mAb})$ generated against recombinant IGFBP-3 ${ }^{\text {E.Coli }}$ (Celtrix Pharmaceuticals Inc., Santa Clara, CA) (15). The assay used $\mathrm{mAb}$ F42-1B6 as the solid phase antibody and mAb F41-5C11 as the Eu-labeled tracer. The intraassay coefficient of variation was 3.6$6.2 \%$ and the interassay coefficient of variation $5.4-11 \%$. The assay had no cross-reactions with the other human IGFBPs or IGFs.

Statistical analyses were based on standard methods used for twin data as follows: Trait values were adjusted by linear regression analyses to adjust for the effect of age and gender, whenever significant gender or both gender and age related effects were detected. No gen-

Table I. Analytical Recovery of Added IGF-II to Serum

\begin{tabular}{lccc}
\hline \multicolumn{4}{c}{ IGF-II Concentration $(\mu \mathrm{g} /$ liter $)$} \\
\hline In serum & Added & Recovered & $\begin{array}{c}\text { Recovery } \\
\text { percent }\end{array}$ \\
\hline 497 & 100 & 622 & 125 \\
285 & 100 & 360 & 75 \\
285 & 50 & 341 & 112 \\
\hline
\end{tabular}

$n=4$ for each experiment.
Table II. IGF-I and -II, and IGFBP-1 and -3 Levels in the Like-sexed Twins

\begin{tabular}{lccl}
\hline & Men $(n=74)$ & Women $(n=84)$ & $P$ value \\
\hline Age (years) & $63.4 \pm 6.7^{*}$ & $61.1 \pm 8.5$ & 0.04 \\
IGF-I (nmol/liter) & $19.3 \pm 5.1$ & $20.1 \pm 5.0$ & 0.38 \\
IGF-II ( $\mu \mathrm{g} /$ liter $)$ & $522.5 \pm 144$ & $653 \pm 175$ & 0.0001 \\
IGFBP-1 ( $\mu \mathrm{g} / \mathrm{liter})$ & $73.1 \pm 71.5$ & $79.8 \pm 40.5$ & 0.46 \\
IGFBP-3 $(\mu \mathrm{g} /$ /iter $)$ & $4496 \pm 1084$ & $5441 \pm 1018$ & 0.001 \\
& & & \\
\hline
\end{tabular}

*Values are means \pm SD.

der by age interactions were found. For IGFBP-1 logarithmic transformation was carried out before statistical analyses to correct for skewness. To estimate genetic and environmental components of variance of the traits, standard univariate twin analyses were carried out (18). These included the test of homogeneity of the mean values and variances across the twin type. Maximum likelihood analyses based on sample covariance matrices were used to estimate the components of variance $(18,19)$. Under the current study design of twins reared together it is possible to model four separate components: (A) an additive genetic component, (D) effects due to dominance, and (C) shared and (E) non-shared environmental components. One can fit the models based on different combinations of these parameters: $\mathrm{AE}, \mathrm{ACE}, \mathrm{ADE}$, and $\mathrm{CE}$ but the effects due to dominance and shared environmental effects cannot be simultaneously modeled with data from twins reared together (19). Chi-square goodness-of-fit statistics were used to assess how well the model fitted the data. The superiority of alternative hierarchically nested models was assessed by the difference of $\chi^{2}$ values of the models which itself is $\chi^{2}$-distributed with degrees of freedom equal to the degrees of freedom of the models to be compared. This was done by comparing first an AE model with an $\mathrm{E}$ model as a test for the presence of significant genetic ef-

Twin 2

IGF - I (nmol/L)

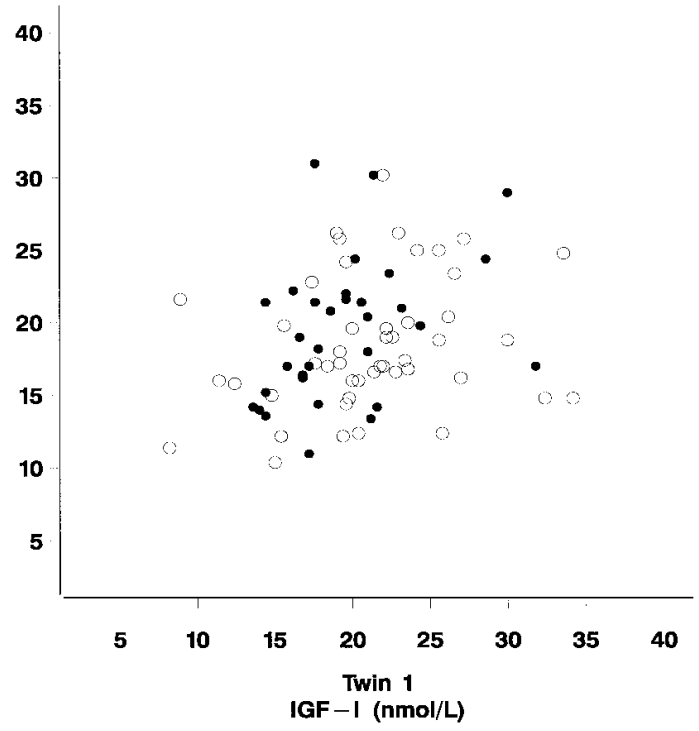

Figure 1. IGF-I levels in twin 1 in relation to those in twin 2 within each pair of monozygotic and dizygotic twins. ( ) Monozygotic; $(\bigcirc)$ dizygotic. The data represents 32 monozygotic and 47 like-sexed dizygotic twin pairs. The intrapair correlations were $r=0.41(P<0.009)$ for monozygotic twins and $r=0.12(P<0.22)$ for dizygotic twins of the same sex. 
fects. Next the AE model was tested against the ADE model as a test for significant non-additive genetic effects, and finally against the ACE model as a test of significant shared environmental effects.

\section{Results}

There were 32 monozygotic and 47 like-sexed dizygotic twin pairs of which 42 were female and 37 male pairs. Women had higher IGF-II levels than men, $653 \pm 175$ vs. $522 \pm 144 \mu \mathrm{g} / \mathrm{liter}$ (mean \pm SD), respectively $(P<0.0001)$. The IGFBP-3 levels were also significantly higher in women compared with men $5441 \pm 1018$ vs. $4496 \pm 1084 \mu \mathrm{g} /$ liter $(P<0.001)$. The differences remained significant after adjustment for age. IGF-II and IGFBP-3 values were adjusted for gender and age before the twin analyses.

The intrapair correlations for the IGF-I levels were $r=$ $0.41(P<0.009)$ for monozygotic twins and $r=0.12(P<0.22)$ for dizygotic twins of the same sex (Fig. 1). The intrapair correlation for the IGF-II concentration was $r=0.66(P<0.0001)$ for monozygotic twins and $r=0.34(P<0.01)$ for dizygotic twins of the same sex (Fig. 2). The correlations for the IGFBP-3 levels were $r=0.65(P<0.0001)$ for monozygotic pairs and $r=0.23(P<0.06)$ for dizygotic pairs of the same sex (Fig. 3). No significant intrapair correlations were found for the IGFBP-1 concentrations in monozygotic twins $r=0.12(P<0.2)$ or dizygotic twins $r=0.18(P<0.1)$.

The estimated heritability, i.e., the proportion of variance attributable to genetic effects in the best fitting AE-model was $38 \%$ for the IGF-I concentration, $66 \%$ for the IGF-II concentration, and $60 \%$ for the IGFBP-3 concentration. For all three traits the E model fitted the data poorly $(P>0.05)$ and additional parameters (D or $C$ ) did not improve the model fit. No

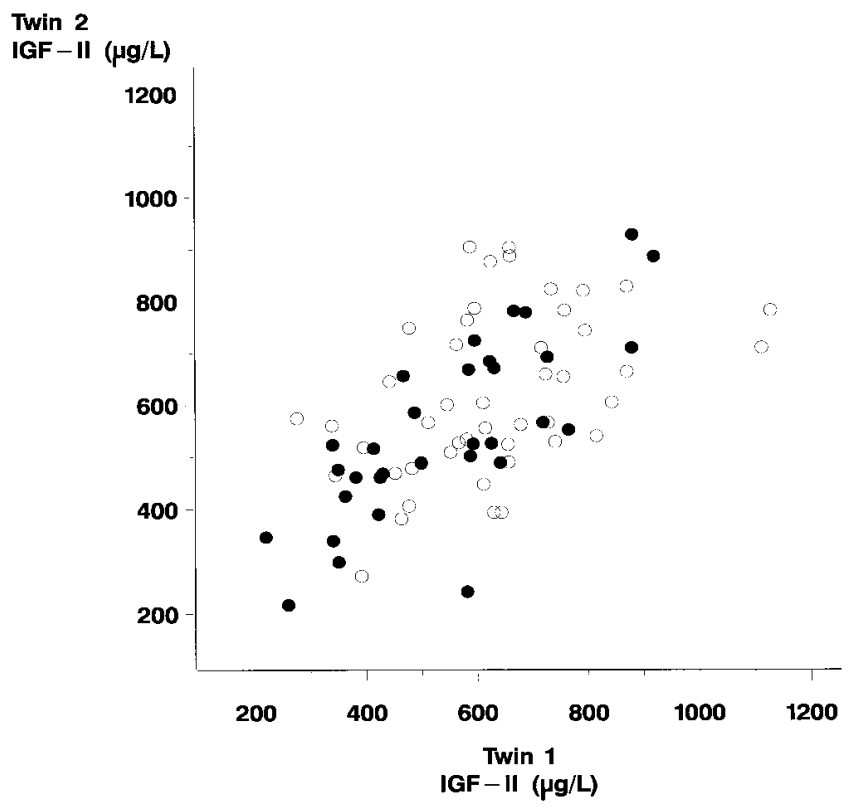

Figure 2. IGF-II levels in twin 1 in relation to those in twin 2 within each pair of monozygotic and dizygotic twins. ( ) Monozygotic; $(\bigcirc)$ dizygotic. The data represents 32 monozygotic and 47 like-sexed dizygotic twin pairs. The intrapair correlation was $r=0.66(P<0.0001)$ for monozygotic twins and $r=0.34(P<0.01)$ for dizygotic twins of the same sex.

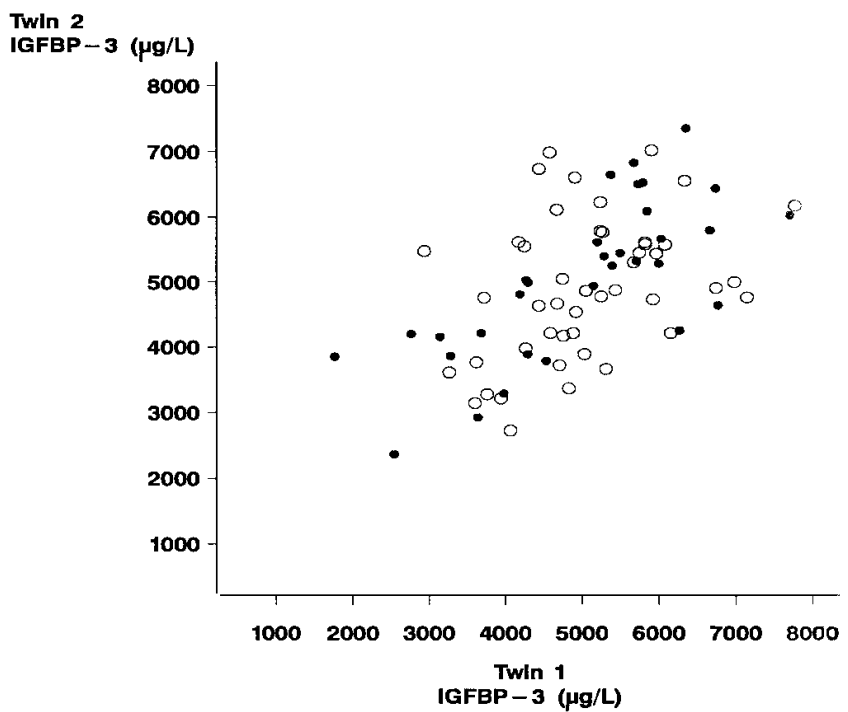

Figure 3. IGFBP-3 levels in twin 1 in relation to those in twin 2 within each pair of monozygotic and dizygotic twins. ( ) Monozygotic; $(\bigcirc)$ dizygotic. The data represents 32 monozygotic and 47 like-sexed dizygotic twin pairs. The intrapair correlation was $r=0.65(P<0.0001)$ for mozygotic twins and $r=0.23(P<0.06)$ for dizygotic pairs of the same sex.

significant heritability was found for the IGFBP-1 concentrations.

\section{Discussion}

The IGF-I and IGFBP-3 levels are age-dependent. Normally serum IGF-I and IGFBP-3 concentrations increase until puberty and decrease thereafter $(20,21)$. We found that the intrapair correlation for the IGF-I levels was much weaker in adult monozygotic twins compared with that reported recently by Kao and colleagues for children (12). This suggests that agerelated factors may affect the expression of the gene.

The variation in IGF-II concentration was most remarkably influenced by the genetic component. To our knowledge, this is the first demonstration of such a relationship based on a representative number of healthy monozygotic and dizygotic twin pairs. Interestingly, women had higher levels than men. The reason for this is not clear yet. The regulation of serum IGF-II concentration is poorly understood, however, there are no significant changes in IGF-II serum concentrations during puberty (1).

Our data showed a more pronounced genetic influence responsible for the variation of serum IGFBP-3 levels compared with previous studies (23). The estimated heritability for the IGFBP-3 levels was much higher than for the IGF-I levels but not as high as for the IGF-II levels. This is not unexpected since the three traits are interrelated and a linear correlation has been reported between the sum of concentrations of IGF-I and IGF-II, and IGFBP-3 (21). Classically serum IGFBP-3 levels are known to vary according to growth hormone secretion (24). Other factors influencing the circulating IGFBP-3 level include age, pubertal development, nutrition, and hepatic function (21). Recent studies have shown that partial proteolysis of IGFBP-3, initially observed in pregnancy sera $(25,26)$, decrease the affinity for IGF-I of this binding protein. Proteol- 
ysis has been detected under various pathological conditions (27-29), but its role under normal physiological circumstances is less clear. IGFBP-3 proteolysis may be regulated by insulin (29) and it may reflect a long-term adaptive process to regulate bioavailability of IGFs whereas IGFBP-1 is the primary regulator on a minute-to-minute basis (30). In our study we found that serum IGFBP-1 levels were regulated solely by environmental factors. However, it is possible that the genetic component was not uncovered due to the wide interindividual variation of fasting serum IGFBP-1 concentrations. The sampling was standardized by obtaining serum from the subjects in the morning after at least eight hours of fasting. However, knowing the substantial diurnal variation of IGFBP-1 levels (2) the highest concentration of IGFBP-1 (fasting) may not necessarily be solely informative as regards to IGFBP-1 production of an individual.

Growth hormone has a dominant role in determining the IGF-I and IGFBP-3 concentrations in serum (22), and growth hormone has a major effect on height. The estimated heritability of height based on the present sample was $92 \%$. The fact that there was no significant correlation between IGFBP-3 and height ( $r=-0.04$, NS) does not bear strong evidence that those genetic factors which mediate height and IGFBP-3 level are closely linked. However, it is conceivable that in younger individuals the genetic impact of serum IGFBP-3 is different. This is supported by studies in children where relative body height, determined largely by growth hormone secretion, is more closely correlated with serum IGFBP-3 levels $(22,31)$ compared with the adults in this study.

We conclude that there is a major genetic component responsible for the variation of serum IGF-II and IGFBP-3 levels and a modest genetic component responsible for the IGF-I levels in adults.

\section{Acknowledgments}

We would like to thank Mrs. Anu Harju for technical assistance.

This study was supported by the Academy of Finland and the University of Helsinki.

\section{References}

1. Daughaday, W.H., and P. Rotwein. 1989. Insulin-like growth factors I and II, peptide, messenger ribonucleic acid and gene structures, serum and tissue concentrations. Endocr. Rev. 10:68-91.

2. Baxter, R.C., and J.L. Martin. 1989. Binding proteins for the insulin-like growth factors: structure, regulation and function. Prog. Growth Factor Res. 1: 49-68.

3. Shimasaki, S., and N. Ling. 1991. Identification and molecular characterization of insulin-like growth factor binding proteins (IGFBP-1, -2, -3, -4, -5 and -6). Prog. Growth Factor Res. 3:243-266.

4. Hintz, R.L., F. Liu, R.G. Rosenfeld, and S.F. Kemp. 1981. Plasma somatomedin-binding proteins in hypopituitarism: changes during growth hormone therapy. J. Clin. Endocrinol. Metab. 53:100-104.

5. Suikkari, A.-M., V.A. Koivisto, E.-M. Rutanen, H. Yki-Järvinen, S.-L. Karonen, and M. Seppälä. 1988. Insulin regulates the serum levels of low molecular weight insulin-like growth factor- binding protein. J. Clin. Endocrinol. Metab. 66:266-272.

6. Angervo, M., P. Leinonen, R. Koistinen, M. Julkunen, and M. Seppälä. 1993. Triiodothyronine and cycloheximide enhance insulin-like growth factorbinding protein-1 gene expression in human hepatoma cells. J. Mol. Endocrinol. 10:7-13.

7. Angervo, M., J.Toivonen, P.Leinonen, M.Välimäki, and M.Seppälä. 1993. Thyroxine withdrawal decreases insulin-like growth factor binding protein-1 levels in thyroidectomized patients. J. Clin. Endocrinol. Metab. 76:1199-1201.
8. Ullrich, A., C.H. Bergman, T.J. Dull, A. Gray, and J.M. Lee. 1984. Isolation of the human insulin-like growth factor I gene using a single synthetic DNA probe. EMBO (Eur. Mol. Biol. Organ.) J. 3:361.

9. de Pagter-Holthuisen, P., F.M.A. van Shaik, G.H. Verduijn, G.J.B. van Ommen, B.N. Bouma, M. Jansen, and J.S. Sussenbach. 1986. Organisation of the human genes for insulin-like growth factors I and II. FEBS Lett. 195:179.

10. Alitalo, T., K. Kontula, R. Koistinen, K. Aalto-Setälä, M. Julkunen, O. Jänne, M. Seppälä, and A. de la Chapelle. 1989. The gene encoding human low molecular weight insulin-like growth factor binding protein (IGFBP25): Regional localisation to $7 \mathrm{p} 12-\mathrm{p} 13$ and description of DNA polymorphism. Hum. Genet. 83:335-338.

11. Ehrenborg, E., C. Larsson, I. Stern, M. Janson, and D.R. Powell. 1992 Contiguous localisation of the genes encoding human insulin-like growth factor binding proteins 1 (IGFBP-1) and 3 (IGFBP-3) on chromosome 7. Genomics. 12:497-502.

12. Kao, P.C., A.P. Matheny, Jr., and C.A. Lang. 1994. Insulin-like growth factor-I comparisons in healthy twin children. J. Clin. Endocrinol. Metab. 78 : 310-312.

13. Kaprio, J., S. Sarna, M. Koskenvuo, and I. Rantasalo. 1978. The Finnish Twin Registry: formation and compilation, questionnaire study, zygosity determination procedures and research program. Prog. Clin. Biol. Res. 24 Pt B:179184.

14. Sarna, S., J. Kaprio, P. Sistonen, and M. Koskenvuo. 1978. Diagnosis of twin zygosity by mailed questionnaire. Hum. Hered. 28:241-254.

15. Koistinen, H., M. Seppälä, and R. Koistinen. 1994. Different forms of insulin-like growth factor binding protein-3 detected in serum and seminal plasma by immunofluorometric assay with monoclonal antibodies. Clin. Chem. 4:531-536.

16. Koistinen, R., O. Itkonen, P. Selenius, and M. Seppälä. 1990. Insulinlike growth factor binding protein-1 inhibits binding of IGF-I on the fetal skin fibroblasts but stimulates their DNA synthesis. Biochem. Biophys. Res. Commun. 173:408-415.

17. Koistinen, H., R. Koistinen, L. Selenius, O. Ylikorkala, and M. Seppälä. Effect of marathon run on serum IGF-I and IGF-binding protein 1 and 3 levels. 1996. J. Appl. Physiol. 80(3). 760-764.

18. Williams, C.J., J.C. Christian, and J.A. Norton, Jr. 1992. TWINAN 90-a Fortran program for conducting ANOVA-based and likelihood-based analyses of twin data. Comput. Methods Programs Biomed. 38:167-176.

19. Neale, M.C., and L.R. Cardon. 1992. Methodology for genetic studies of twins and families. Kluwer Academic Publishers, Dordrechr, The Netherlands.

20. Hall, K., and V.R. Sara. 1984. Somatomedin levels in childhood, adolescence and adult life. J. Clin. Endocrinol. Metab. 13:91-112.

21. Blum, W.F., and M.B. Ranke. 1991. Plasma IGFBP-3 levels as clinical indicators. In Modern Concepts of Insulin-like Growth Factors. E.M. Spencer, editor. Elsevier Science, New York. 381-393.

22. Blum, W.F., K. Albertssons-Wikland, S. Rosberg, and M.B. Ranke. 1993. Serum levels of insulin-like growth factor-I and IGF binding protein-3 reflect spontaneous growth hormone secretion. J. Clin. Endocrinol. Metab. 76 1610-1616.

23. Jahanfar, S., J. A. Eden, P. Warren, M. Seppälä, and T.V. Nguyen. 1995. A twin study of polycystic ovary syndrome. Fertil. Steril. 63:478-486.

24. Cohen, K.L., and S. P. Nissley. 1976. The serum half-life of somatomedin activity: evidence for growth hormone dependence. Acta endocrinol. 83: 243-258.

25. Giudice, L.C., E.M. Farrell, H. Pham, G. Lamson, and R.G. Rosenfeld. 1990. Insulin-like growth factor binding proteins in maternal serum throughout gestation and in the puerperium: effects of a pregnancy-associated serum protease activity. J. Clin Endocrinol. Metab. 71:806-816.

26. Davenport, M.L., D.R. Clemmons, M.V. Miles, C. Camacho-Hubner, A.J. D'Ercole, and L.E. Underwood. 1990. Regulation of serum insulin-like growth factor-I (IGF-I) and IGF binding proteins during rat pregnancy. Endocrinology. 127:1278-1286.

27. Davies, S.C., J.A. Wass, R.J. Ross, A.M. Cotterill, C.R. Buchanan, V.J. Coulson, and J.M. Holly. 1991. The induction of specific protease for insulin like growth factor binding protein-3 in the circulation during severe illness. $J$. Endocrinol. 130:469-473.

28. Davenport, M., W. Isley, J. Pucilowskaja, L. Pemberton, B. Lyman, L. Underwood, and D. Clemmons. 1992. Insulin-like growth factor-binding protein-3 proteolysis is induced after elective surgery. J. Clin. Endocrinol. Metab. 75:590-595.

29. Bereket, A., C.H. Lang, S.L. Blethen, J. Fan, R.A. Frost, and T.A. Wilson. 1995. Insulin-like growth factor binding protein-3 proteolysis in children with insulin-dependent diabetes mellitus: a possible role for insulin in the regulation of IGFBP-3 protease activity. J. Clin. Endocrinol. Metab. 80:2282-2288.

30. Giudice, L.C. 1995. IGF binding protein-3 protease regulation: How sweet it is! J . Clin. Endocrinol. Metab. 80: 2279-2281.

31. Vihervuori, E., M. Virtanen, H. Koistinen, R. Koistinen, M. Seppälä, and M.A. Siimes. 1996. Hemoglobin level is linked to growth hormone-dependent proteins in short children. Blood. 87:2075-2081. 